\title{
Pharmacological, medicinal and toxicological properties of lavender essential oil: A
}

\section{review}

\author{
Propriedades farmacológicas, medicinais e toxicológicas do óleo essencial de lavanda: Uma revisão \\ Propiedades farmacológicas, medicinales y toxicológicas del aceite esencial de lavanda: Una \\ revisión
}

Received: 04/11/2021 | Reviewed: 04/18/2021 | Accept: 04/20/2021 | Published: 05/08/2021

Gabriel Fernando Esteves Cardia ORCID: https://orcid.org/0000-0003-3781-7498 State University of Maringá, Brazil E-mail: g_cardia@hotmail.com

Francielli Maria de Souza Silva-Comar ORCID: https://orcid.org/0000-0001-6840-9345 State University of Maringá, Brazil E-mail: franciellimss@gmail.com

Edvalkia Magna Teobaldo da Rocha ORCID: https://orcid.org/0000-0003-3011-9849 State University of Maringá, Brazil E-mail:pg401988@uem.br

Saulo Euclides Silva-Filho

ORCID: https://orcid.org/0000-0002-9676-7622 Federal University of Mato Grosso do Sul, Brazil E-mail: saulo.esf@gmail.com

Mayara Zagoto

ORCID: https://orcid.org/0000-0002-9856-0510 State University of Maringá, Brazil E-mail: mayara_zagotto@hotmail.com Nancy Sayuri Uchida

ORCID: https://orcid.org/0000-0003-1586-4111 State University of Maringá, Brazil E-mail: n.sayuri@hotmail.com

Valeria do Amaral

ORCID: https://orcid.org/0000-0002-6503-5269 State University of Maringá, Brazil E-mail: doamaralvaleria@gmail.com

Ciomar Aparecida Bersani-Amado ORCID: https://orcid.org/0000-0002-0247-2090 State University of Maringá, Brazil E-mail: cabamado@uem.br

Roberto Kenji Nakamura Cuman ORCID: https://orcid.org/0000-0002-4906-887X State University of Maringá, Brazil E-mail: rkncuman@uem.br

\begin{abstract}
The natural products extracted from plants are part of traditional medicine and are also therapeutic possibilities for treating many diseases. Recently, its use in the development of new drugs has shown much visibility for its efficiency and few adverse effects. Essential oils extracted from medicinal plants are indicated to treat numerous diseases due to their antimicrobial, antiviral, antimutagenic, anticancer, antioxidant, anti-inflammatory, immunomodulatory, and antiprotozoal properties. Among essential oils, lavender essential oil stands out for having several important pharmacological properties. This review detailed the main studies on essential oils from different species of lavender and obtained a valuable collection on all their pharmacological, medicinal and toxicological potential. In this context, we evaluated lavender essential oil as a promising substance that can help treat several diseases. We provide some evidence and an overview of the potential therapeutic effect of lavender essential oil to guide new research.
\end{abstract}

Keywords: Lavenders; Essential oils; Therapeutic potentials; Biological properties.

\section{Resumo}

In Os produtos naturais extraídos das plantas fazem parte da medicina tradicional e também são possibilidades terapêuticas para o tratamento de muitas doenças. Recentemente, seu uso no desenvolvimento de novos medicamentos 
tem mostrado muita visibilidade por sua eficácia e poucos efeitos adversos. Os óleos essenciais extraídos de plantas medicinais são indicados para o tratamento de inúmeras doenças devido às suas propriedades antimicrobiana, antiviral, antimutagênica, anticâncer, antioxidante, antiinflamatória, imunomoduladora e antiprotozoária. Dentre os óleos essenciais, o óleo essencial de lavanda se destaca por possuir diversas propriedades farmacológicas importantes. Esta revisão detalhou os principais estudos sobre os óleos essenciais de diferentes espécies de lavanda e obteve um valioso acervo sobre todo o seu potencial farmacológico, medicinal e toxológico. Nesse contexto, avaliamos o óleo essencial de lavanda como uma substância promissora que pode auxiliar no tratamento de diversas doenças. Fornecemos algumas evidências e uma visão geral do potencial efeito terapêutico do óleo essencial de lavanda para orientar novas pesquisas. Palavras-chave: Lavandas; Óleos essenciais; Potencial terapêutico; Propriedades biológicas.

\section{Resumen}

Los productos naturales extraídos de las plantas forman parte de la medicina tradicional y también son posibilidades terapéuticas para el tratamiento de muchas enfermedades. Recientemente, su uso en el desarrollo de nuevos fármacos ha mostrado mucha visibilidad por su eficacia y pocos efectos adversos. Los aceites esenciales extraídos de plantas medicinales están indicados para tratar numerosas enfermedades por sus propiedades antimicrobianas, antivirales, antimutagénicas, anticancerígenas, antioxidantes, antiinflamatorias, inmunomoduladoras y antiprotozoarias. Entre los aceites esenciales, el aceite esencial de lavanda se destaca por tener varias propiedades farmacológicas importantes. Esta revisión detalló los principales estudios sobre aceites esenciales de diferentes especies de lavanda y obtuvo una valiosa colección sobre todo su potencial farmacológico. En este contexto, evaluamos el aceite esencial de lavanda como una sustancia prometedora que puede ayudar a tratar varias enfermedades. Proporcionamos algunas pruebas y una descripción general del posible efecto terapéutico del aceite esencial de lavanda para guiar nuevas investigaciones. Palabras clave: Lavandas; Aceites esenciales; Potenciales terapéuticos; Propiedades biológicas.

\section{Introduction}

The natural products extracted from plants are part of traditional medicine and are therapeutic possibilities for treating various diseases (Thomford et al., 2018). Recently, its use in the production of new drugs has shown much visibility for its efficiency (Es-Safi et al., 2020; Newman \& Cragg, 2012).

In this context, the active compounds extracted from medicinal plants in the form of essential oil have several pharmacological activities (Bakkali et al., 2008). Essential oils are secondary metabolites found in natural products consisting mainly of terpenoids, such as monoterpenes and sesquiterpenes (Bakkali et al., 2008).

Essential oils are recommended to treat numerous diseases due to their antimicrobial, antiviral, antimutagenic, anticancer, antioxidant, anti-inflammatory, immunomodulatory, and antiprotozoal properties (Dhifi et al., 2016; Sharifi-Rad et al., 2017). Thus, new treatment methods using natural products are being developed for human health, considering its low cost and few adverse effects (Carson \& Riley, 2003).

Among essential oils, lavender essential oil stands out for having several important pharmacological properties to treat many health problems (Wells et al., 2018). Therefore, in the next section, we provide some evidence and an overview of the potential therapeutic effect of lavender essential oil to guide new research.

\section{Methods}

We adopted the narrative review methodology, a qualitative study suitable for discussing a given subject and a comprehensive analysis of the literature. This analysis and interpretation of works in the literature facilitate identifying existing problems and gaps to assist in the development of new research (Sant'Anna Ramos Vosgerau \& Paulin Romanowski, 2014). A literature review was performed using the following search terms: Essential oil and Lavender or Essential oil and Lavandula. The research included literature until March 2021 in four electronic databases (PubMed, Scopus, Web of Science and Google Scholar). No restrictions were placed in the year of publication for the articles included. The research included articles on humans and animals, in the English language and that contained abstract. The titles and abstracts of the publications were reviewed and after an initial screening of the abstract, the publications that were potentially eligible were reviewed in their entirety and included in the review. 


\section{Results and Discussion}

\section{Lavender essential oil}

The Lamiaceae family can be found in practically all-natural ecosystems and comprises more than 200 genera with approximately 6000 species (Salehi et al., 2018). Several species of the Lamiaceae family have valuable essential oils for use in medicinal purposes with several pharmacological properties such as antibacterial, anti-inflammatory, antioxidants and, antivirals, in addition to being widely used in the cosmetics and perfumery industries (Mamadalieva et al., 2017; Raja, 2012). Plants of the Lavandula genus are native to the Mediterranean. However, nowadays, they are grown worldwide due to the constituents of their essential oils that have aromatic and medicinal properties highly valued in the pharmaceutical and cosmetic industry and, currently, in aromatherapy products (Lis-Balchin, 2002; Salehi et al., 2018). Besides, the lavender plants are widely used for decorating environments (Touati et al., 2011). However, its importance is predominantly related to the characteristics of its essential oils, which have internationally regulated standards and have been used for centuries (Cavanagh \& Wilkinson, 2002; Woronuk et al., 2011).

The first registers of the use of lavender as an alternative treatment can be found in ancient Greece, and currently, the interest in using it as an alternative treatment for various diseases has been increasing, making lavender and its essential oils very popular (Woronuk et al., 2011). Lavender was widely used in Italy as an antiseptic used after bathing. Besides, it was considered an aphrodisiac plant. On the other hand, oriental medicine uses lavender essential oil for its anxiolytic activity (Samuelson et al., 2020). Currently, many researchers are dedicated to investigating the historical use of lavender and, in this way, several important pharmacological properties such as antioxidants, antibacterial, anxiolytics, analgesics, and anti-inflammatories have been found. These activities may be related to the activity of their terpenoid constituents (Cardia et al., 2018; Generoso et al., 2017; Miladinović et al., 2012; Silva et al., 2015).

The use of essential oils in aromatherapy is widely practiced for the numerous benefits that are found (Cavanagh \& Wilkinson, 2002). Several studies have proven that lavender oil can stimulate and improve sleep, reducing stress and anxiety (Bradley et al., 2007; Dobetsberger \& Buchbauer, 2011; Gonçalves \& Romano, 2013; Hallschmid et al., 2004). Besides, evidence suggests the use of lavender for the treatment of dementia (Smallwood et al., 2001). Other studies suggest using lavender essential oil to treat several health problems due to the important pharmacological activities presented as antimicrobial, anti-inflammatory, antioxidant and, agent anticholinesterase (Cardia et al., 2018; Costa et al., 2012; Hanamanthagouda et al., 2010). A large part of these pharmacological activities found in lavender is their active metabolites, such as flavonoids and phenolic acids, that present several important activities (Costa et al., 2011; Spiridon et al., 2011). Besides, lavender oils are widely used by the food industry, cosmetics, and cleaning products, as in soaps, shampoos, detergents, perfumes, beverages, and food flavorings, due to their pleasant aroma (Bakkali et al., 2008). In this way, all these properties make lavender essential oil stand out in the market.

As explained earlier, essential oils extracted from plants are complex mixtures composed of terpenes, monoterpenes, and aromatic compounds, usually with some main constituents (Bakkali et al., 2008; Isman et al., 2011). However, essential oils' characteristics vary due to different factors, such as plant species, climatic conditions, time of harvest, and extraction method. These conditions can modify the amount of main constituents present in the oil (Cheng et al., 2009; Rahimzadeh et al., 2016).

In this way, essential oils' pharmacological and therapeutic properties may be due to an isolated or synergistic effect of the constituents present in the essential oil (Lesage-Meessen et al., 2015). Several studies have shown that the main constituents identified in most lavender essential oils are 1,8-cineole, borneol, camphor, linalool, thymol, $\alpha$-pinene, $\beta$-pinene, and $\rho$-cymene (Ebadollahi et al., 2020; Woronuk et al., 2011).

Several studies with isolated compounds present in lavender essential oil, such as linalool and linalyl acetate, have shown sedative, anesthetic, and antispasmodic actions. Antimicrobial, antioxidant, and anti-inflammatory activities have been found in constituents such as linalool, 1,8-cineole, camphor, and terpineol (Angioni et al., 2006; Blažeković et al., 2010; 
Cavanagh \& Wilkinson, 2002; Lis-Balchin \& Hart, 1999; Lis-Balchin, 2002; Moon et al., 2007). In addition, Linalool, linalyl acetate, and 1,8-cineole have antispasmodic action. Some insecticidal activities have been determined for linalool, and narcotic activities have been found in linalyl acetate (Lesage-Meessen et al., 2015).

\section{Lavender essential oil in Wound healing}

Over the years, several studies have been produced to evaluate the healing activity of many products. Among them, the lavender essential oil stands out with several evidences of its healing effect. Historically the use of lavender essential oil as a healing agent was discovered in France by chance after a chemist applied the oil over a burn on his hand and described a complete recovery process. Besides, oil was widely used during World War II to heal soldiers' wounds (Samuelson et al., 2020).

Studies recommend the topical use of lavender essential oil as a healing agent for speeding up the process of contracting skin lesions and also presenting antimicrobial activity (Altaei, 2012; Ben Djemaa et al., 2016; Mori et al., 2016; Predoi et al., 2018; Vasireddy et al., 2018). Several mechanisms of action are suggested to determine the effect of lavender oil on wound healing. Research has shown that lavender essential oil increases levels of transforming growth factor (TGF)- $\beta$, thereby induces an increase in the production of fibroblasts and type I collagen that would assist in improving the injury (Mori et al., 2016). In addition, treatment with lavender essential oil has been shown to increase the amount of fibroblast growth factor-2 (FGF-2) and epidermal growth factor (EGF) (Koca Kutlu et al., 2013). This scaring effect of lavender essential oil may be due to an isolated or synergistic effect of the oil's constituents, such as linalyl acetate and linalool, which also have healing activity (Li et al., 2016).

\section{Lavender essential oil in Aromatherapy}

Aromatherapy is a resource used in alternative medicine to treat various disorders using massages, inhalation, or baths (Buckle, 1999; Cooke \& Ernst, 2000). The use of lavender essential oil in aromatherapy is widespread. Studies indicate that the aroma exhaled by the wash is effective in reducing anxiety and pain, being a procedure used by many women during childbirth, is considered a safe technique capable of decreasing cortisol and anxiety levels (Ezzo, 2007; Mirzaei, Keshtgar, Kaviani, 2015).

Besides, several clinical trials have determined the ability of lavender essential oil to treat patients with some degree of dementia. It has been shown that the use of aromatherapy with lavender essential oil can reduce body agitation, and when combined with massage therapy, excessive motor behaviour has also been reduced (Holmes et al., 2002; Smallwood et al., 2001). The dermal application of creams containing lavender essential oil was also able to reduce the cognitive impairment of patients with dementia (Joy Bowles, 2002). Although many researches indicate the use of aromatherapy for the treatment of psychological disorders, the studies present several methodological restrictions that can interfere in the interpretation of the results, mainly due to the lack of standardization of the dosage used, however, the published results are quite promising and other studies must be developed (Woronuk et al., 2011).

The use of lavender oil to improve sleep is a practice used for many years. Several studies have proven its effectiveness, increasing the duration of deep sleep in both babies and the elderly (Field et al., 2008; Goel et al., 2005; Hudson, 1996). Besides, lavender essential oil decreased the anxiety levels of intensive care unit patients treated with lavender aromatherapy (Dunn et al., 1995).

\section{Anxiolytic effects of lavender essential oils}

There are many reports of the medicinal use of lavender due to its anxiolytic and soothing activity. Anxiety is a disease that affects many people worldwide. Although it is simple, it can get worse and be debilitating, requiring treatment with drugs. Thus, the use of lavender can be an alternative for a lighter treatment than the conventional ones since it does not present many allergic reactions or gastrointestinal complaints (Cavanagh \& Wilkinson, 2002; Coulson \& Khan, 1999; Leung \& Foster, 1996; 
Wittchen et al., 2011).

A study with the essential oil of lavender in animals suggested an anxiolytic activity with the treatment with essential oil of lavender. However, depending on the dose, the treatment can reduce the animals' mobility presenting a sedative effect (Shaw et al., 2007). On the other hand, another study showed the activity of lavender essential oil in animals submitted to the test in the open field and concluded that the treatment with lavender inhalation had an anxiolytic effect without reducing the animals' mobility. The authors concluded that the anxiolytic activity of Lavender oil could be mediated by a different mechanism of action than benzodiazepines (Shaw et al., 2011). Besides, the inhalation of lavender essential oil demonstrated an anxiolytic effect, both in stressed animals and in non-stressed animals (Takahashi et al., 2012).

Clinical research has assessed the anxiolytic effect of lavender essential oil. It has shown that patients who have been exposed to aromatherapy have experienced a significant decrease in anxiety conditions due to an effect on the central nervous system, suggesting that lavender essential oil may have a similar action. With benzodiazepines, the use of lavage can therefore be indicated for complementary treatments in patients with anticipatory anxiety (Kritsidima et al., 2010; Tasev et al., 1969; Tisserand, 1988).

The anxiolytic effect of lavender essential oil has proven its effectiveness. There is already a medicine called Silexan, produced with lavender essential oil and indicated for patients with anxiety disorder (Kasper et al., 2010). Experimental animal studies using the elevated plus-maze model showed that treatment with Silexan had an anxiolytic effect, increasing animal exploitation in the environment and social interaction. However, the treatment also showed changes in the animals' motor activity (Kumar, 2013). Another study also using Silexan demonstrated that the animals that were treated had an anxiolytic effect by increasing the exploration of open arms in the elevated plus-maze model, and the authors concluded that the anxiolytic effect of Silexan could be related to the inhibition of kennels of calcium, showing similarities with pregabalin (Schuwald et al., 2013).

\section{Lavender essential oil alleviates pain and inflammation}

Lavender is an alternative therapy for treating pain and inflammation used in several countries (Djenane et al., 2012). In this sense, many clinical researchers have reported that treatment with aromatherapy or inhalation of lavender essential oil provides a reduction in the pain and inflammation of patients with different types of diseases, such as pediatric, postoperative pain, labor, and various chronic inflammatory diseases (Cardia et al., 2018; Nasiri et al., 2016; Olapour et al., 2013; Ou et al., 2012; Soltani et al., 2013; Yazdkhasti \& Pirak, 2016). Besides, the topical application of lavender essential oil effectively reduces pain perception in patients with carpal tunnel syndrome, showing the possible effect of lavender oil on neuropathic pain (Eftekharsadat et al., 2018).

The essential oils of several different lavender plants are being used to treat wounds and burns due to their antiinflammatory activities (Cavanagh \& Wilkinson, 2002; Ez zoubi et al., 2020). Other studies show that lavender essential oil is an important inflammatory agent in preventing liver and kidney damage, reducing the inflammatory process, and inhibiting oxidative stress, proving to be an excellent alternative for treating liver diseases (Aboutaleb et al., 2019; Cardia et al., 2021; Kozics et al., 2017).

Several works were produced to find the possible anti-inflammatory mechanisms of lavender essential oil. Lavender oil treatment has been shown to reduce nitric oxide and various pro-inflammatory cytokines and reduce the inflammatory process in different experimental models (Cardia et al., 2018, 2021; Neves et al., 2010; Zuzarte et al., 2013). In this sense, some studies have determined the anti-inflammatory activity isolated from the main constituents of lavender essential oil, such as 1.8 cineol, camphor, linalool, and linalyl acetate, and have evidenced the significant anti-inflammatory and antiedematogenic effect present in these constituents (Hajhashemi et al., 2003; Peana et al., 2006; Silva-Filho et al., 2015). Another study also demonstrated the anti-inflammatory and cardioprotective activity of lavender essential oil, and the proposed mechanism was due to the antioxidant 
activity of its main constituents (Ziaee et al., 2015). Thus, the use of constituents of lavender essential oil in the clinical treatment of different diseases is very promising due to the great anti-inflammatory potential. However, more research is important to deepen the mechanisms of action of these constituents (Peana et al., 2006).

\section{Antioxidant Properties of Lavender essential oil}

The antioxidant activity of several natural products, mainly essential oils and compounds isolated from medicinal plants, has gained much interest due to its enormous potential. Several studies have highlighted the antioxidant potential of lavender (Cardia et al., 2021; Dif et al., 2017; Matos et al., 2009). Lavender extracts have antioxidant activity due to their numerous constituents, especially flavonoids and isoprenoids (Tsai et al., 2008). The essential oil of Lavandula officinalis demonstrated hepatoprotective activity due to its ability to inhibit oxidative stress and increase levels of antioxidant enzymes (Cardia et al., 2021). Likewise, Lavandula angustifolia also showed antioxidant activity against lipid peroxidation in a myocardial infarction model in rats (Hui et al., 2010; Ziaee et al., 2015). In addition, another study compared the antioxidant activity of different species of lavender, and Lavandula dentata showed the greatest ability to scavenge free radicals (Dif et al., 2017).

\section{Lavender essential oil in Cosmetics}

Lavender essential oils are well known and valued by the cosmetic industry, and their constituents are often used in beauty products mainly for their pleasant aroma (Cavanagh \& Wilkinson, 2002; Dreger \& Wielgus, 2013). The various species of lavender have different characteristics. Lavandula angustifolia oil has been used in fragrances, cosmetics, and medicines. Besides, the essential oils of Lavandula hybrids are indicated for the anti-louse treatment (Sarkic \& Stappen, 2018). Several studies have demonstrated the potential use of essential oil as a natural preservative in cosmetics and beauty products as a substitute for synthetic preservatives that can cause allergic reactions in some consumers (Carvalho et al., 2016; Ghica et al., 2016; Herman et al., n.d.). However, the use of lavender oil in cosmetics must be correctly labeled in products, as we will report in the next topic, some consumers may suffer from contact dermatitis and allergies to some constituents present in the oil.

\section{Toxicity of Lavender essential oil}

The oral use of several essential oils without dilution is not indicated as a result of some irritating or cytotoxic effects. Thus, the dilution of the oils is necessary for administration. However, toxicity from the use of lavender is uncommon (Jenner et al., 1964). Lavender essential oil did not demonstrate cytotoxicity in vitro, and in mice, oral administration was considered safe, with an LD50 of $13.5 \mathrm{~g} / \mathrm{kg}$ (Cardia et al., 2018; Jenner et al., 1964) However, one study evaluated the in vitro genotoxicity of lavender essential oil and its main constituents in the proliferation of lymphocytes. Lavender essential oil and linalool, its main constituent, was considered safe. However, linalyl acetate may have aneugenic activity (Di Sotto et al., 2011). Another in vitro study determined that lavender essential oil damages the cell membrane of human skin (Prashar et al., 2004). Also, some previous work has shown that lavender extract and some of its constituents, such as linalool and linalyl acetate, can cause contact dermatitis in patients with cosmetic dermatitis (Sugiura et al., 2000; Thomson \& Wilkinson, 2000). Anyway, several clinical studies present in this review used lavender essential oil in high concentrations and did not show irritability in contact with the skin.

\section{Conclusion}

Nowadays, the demand for natural products has been increasing more and more, and in this way, the interest in the pharmacological activities of essential lavender oils is being detached. This review detailed the main studies on the different essential oils of lavender and obtained a valuable collection on all their pharmacological potential. In this context, the current 
body of literature suggests the lavender essential oil as a very promising substance that has several pharmacological activities such as anti-inflammatory (Cardia et al., 2018), hepatoprotective (Cardia et al., 2021), antidepressant and anxiolytic (Woelk \& Schläfke, 2010), cardioprotective (Ziaee et al., 2015), analgesic (Silva et al., 2015), wound healing (Mori et al., 2016), antimicrobial and antioxidant (Cardia et al., 2021; Niksic et al., 2017). Thus, with all these properties found in lavender essential oils, new research is important to expand knowledge and use in clinical conditions to determine the therapeutic efficacy of lavender oils.

\section{Acknowledgments}

This study was supported by grants from CAPES (Coordenadoria de Aperfeiçoamento de Pessoal de Nível Superior) and CNPq (Conselho Nacional de Desenvolvimento Científico e Tecnológico), Brazil.

\section{References}

Aboutaleb, N., Jamali, H., Abolhasani, M., \& Pazoki Toroudi, H. (2019). Lavender oil (Lavandula angustifolia) attenuates renal ischemia/reperfusion injury in rats through suppression of inflammation, oxidative stress and apoptosis. Biomedicine \& Pharmacotherapy, 110, 9-19.

Altaei, D. T. (2012). Topical lavender oil for the treatment of recurrent aphthous ulceration. American Journal of Dentistry, 25(1), 39-43.

Angioni, A., Barra, A., Coroneo, V., Dessi, S., \& Cabras, P. (2006). Chemical Composition, Seasonal Variability, and Antifungal Activity of Lavandula stoechas L. ssp. stoechas Essential Oils from Stem/Leaves and Flowers. Journal of Agricultural and Food Chemistry, 54(12), 4364-4370.

Bakkali, F., Averbeck, S., Averbeck, D., \& Idaomar, M. (2008). Biological effects of essential oils - A review. Food and Chemical Toxicology, 46(2), 446-475.

Ben Djemaa, F. G., Bellassoued, K., Zouari, S., El Feki, A., \& Ammar, E. (2016). Antioxidant and wound healing activity of Lavandula aspic L. ointment. Journal of Tissue Viability, 25(4), 193-200.

Blažeković, B., Vladimir-Knežević, S., Brantner, A., \& Štefan, M. (2010). Evaluation of Antioxidant Potential of Lavandula x intermedia Emeric ex Loisel. "Budrovka": A Comparative Study with L. angustifolia Mill. Molecules, 15(9), 5971-5987.

Bradley, B. F., Starkey, N. J., Brown, S. L., \& Lea, R. W. (2007). Anxiolytic effects of Lavandula angustifolia odour on the Mongolian gerbil elevated plus maze. Journal of Ethnopharmacology, 111(3), 517-525.

Buckle, J. (1999). Aromatherapy inperianesthesia nursing. Journal of PeriAnesthesia Nursing, 14(6), 336-344.

Cardia, G. F. E., Silva-Comar, F. M. de S., Silva, E. L., Rocha, E. M. T. da, Comar, J. F., Silva-Filho, S. E., Zagotto, M., Uchida, N. S., Bersani-Amado, C. A., \& Cuman, R. K. N. (2021). Lavender (Lavandula officinalis) essential oil prevents acetaminophen-induced hepatotoxicity by decreasing oxidative stress and inflammatory response. Research, Society and Development, 10(3), e43410313461.

Cardia, G. F. E., Silva-Filho, S. E., Silva, E. L., Uchida, N. S., Cavalcante, H. A. O., Cassarotti, L. L., Salvadego, V. E. C., Spironello, R. A., Bersani-Amado, C. A., \& Cuman, R. K. N. (2018). Effect of Lavender (Lavandula angustifolia) Essential Oil on Acute Inflammatory Response. Evidence-Based Complementary and Alternative Medicine, 2018, 1-10.

Carson, C. F., \& Riley, T. V. (2003). Non-antibiotic therapies for infectious diseases. Communicable Diseases Intelligence Quarterly Report, 27 Suppl, S143-6. Carvalho, I. T., Estevinho, B. N., \& Santos, L. (2016). Application of microencapsulated essential oils in cosmetic and personal healthcare products - a review. International Journal of Cosmetic Science, 38(2), 109-119.

Cavanagh, H. M. A., \& Wilkinson, J. M. (2002). Biological activities of Lavender essential oil. Phytotherapy Research, 16(4), $301-308$.

Cheng, S.-S., Chua, M.-T., Chang, E.-H., Huang, C.-G., Chen, W.-J., \& Chang, S.-T. (2009). Variations in insecticidal activity and chemical compositions of leaf essential oils from Cryptomeria japonica at different ages. Bioresource Technology, 100(1), 465-470.

Cooke, B., \& Ernst, E. (2000). Aromatherapy: a systematic review. The British Journal of General Practice: The Journal of the Royal College of General Practitioners, 50(455), 493-496.

Costa, P., Gonçalves, S., Andrade, P. B., Valentão, P., \& Romano, A. (2011). Inhibitory effect of Lavandula viridis on Fe(2+)-induced lipid peroxidation, antioxidant and anti-cholinesterase properties. Food Chemistry, 126(4), 1779-1786. https://doi.org/10.1016/j.foodchem.2010.12.085

Costa, P., Grosso, C., Gonçalves, S., Andrade, P. B., Valentão, P., Gabriela Bernardo-Gil, M., \& Romano, A. (2012). Supercritical fluid extraction and hydrodistillation for the recovery of bioactive compounds from Lavandula viridis L'Hér. Food Chemistry, 135(1), $112-121$.

Coulson, I. H., \& Khan, A. S. (1999). Facial “pillow” dermatitis due to lavender oil allergy. Contact Dermatitis, $41(2), 111$.

Dhifi, W., Bellili, S., Jazi, S., Bahloul, N., \& Mnif, W. (2016). Essential Oils' Chemical Characterization and Investigation of Some Biological Activities: A Critical Review. Medicines, 3(4), 25.

Di Sotto, A., Mazzanti, G., Carbone, F., Hrelia, P., \& Maffei, F. (2011). Genotoxicity of lavender oil, linalyl acetate, and linalool on human lymphocytes in 
vitro. Environmental and Molecular Mutagenesis, 52(1), 69-71.

Dif, M. M., Benyahia, M., Toumi Benali, F., Rahmani, M., \& Bouazza, S. (2017). Phenolic content and antioxidant activity of three algerian species of lavenders. Phytothérapie, 15(6), 367-372.

Djenane, D., Aïder, M., Yangüela, J., Idir, L., Gómez, D., \& Roncalés, P. (2012). Antioxidant and antibacterial effects of Lavandula and Mentha essential oils in minced beef inoculated with E. coli O157:H7 and S. aureus during storage at abuse refrigeration temperature. Meat Science, 92(4), 667-674.

Dobetsberger, C., \& Buchbauer, G. (2011). Actions of essential oils on the central nervous system: An updated review. Flavour and Fragrance Journal, 26(5), $300-316$.

Dreger, M., \& Wielgus, K. (2013). Application of essential oils as natural cosmetic preservatives. Herba Polonica, 59(4), 142-156.

Dunn, C., Sleep, J., \& Collett, D. (1995). Sensing an improvement: an experimental study to evaluate the use of aromatherapy, massage and periods of rest in an intensive care unit. Journal of Advanced Nursing, 21(1), 34-40.

Ebadollahi, A., Ziaee, M., \& Palla, F. (2020). Essential Oils Extracted from Different Species of the Lamiaceae Plant Family as Prospective Bioagents against Several Detrimental Pests. Molecules, 25(7), 1556.

Eftekharsadat, B., Roomizadeh, P., Torabi, S., Heshmati-Afshar, F., Jahanjoo, F., \& Babaei-Ghazani, A. (2018). Effectiveness of Lavendula stoechas essential oil in treatment of mild to moderate carpal tunnel syndrome: A randomized controlled trial. Journal of Hand Therapy, 31(4), 437-442.

Es-Safi, I., Mechchate, H., Amaghnouje, A., El Moussaoui, A., Cerruti, P., Avella, M., Grafov, A., \& Bousta, D. (2020). Marketing and legal status of phytomedicines and food supplements in Morocco. Journal of Complementary and Integrative Medicine.

Ez zoubi, Y., Bousta, D., \& Farah, A. (2020). A Phytopharmacological review of a Mediterranean plant: Lavandula stoechas L. Clinical Phytoscience, 6(1), 9. Ezzo, J. (2007). What Can Be Learned from Cochrane Systematic Reviews of Massage That Can Guide Future Research? The Journal of Alternative and Complementary Medicine, 13(2), 291-296.

Field, T., Field, T., Cullen, C., Largie, S., Diego, M., Schanberg, S., \& Kuhn, C. (2008). Lavender bath oil reduces stress and crying and enhances sleep in very young infants. Early Human Development, 84(6), 399-401.

Generoso, M. B., Soares, A., Taiar, I. T., Cordeiro, Q., \& Shiozawa, P. (2017). Lavender Oil Preparation (Silexan) for Treating Anxiety. Journal of Clinical Psychopharmacology, 37(1), 115-117.

Ghica, M. V., Albu, M. G., Kaya, D. A., Popa, L., Öztürk, Șevket, Rusu, L.-C., Dinu-Pîrvu, C., Chelaru, C., Albu, L., Meghea, A., \& Nitipir, C. (2016). The effect of lavandula essential oils on release of niflumic acid from collagen hydrolysates. Korean Journal of Chemical Engineering, 33(4), 1325-1330.

Goel, N., Kim, H., \& Lao, R. P. (2005). An Olfactory Stimulus Modifies Nighttime Sleep in Young Men and Women. Chronobiology International, 22(5), 889904. https://doi.org/10.1080/07420520500263276

Gonçalves, S., \& Romano, A. (2013). In vitro culture of lavenders (Lavandula spp.) and the production of secondary metabolites. Biotechnology Advances, $31(2), 166-174$

Hajhashemi, V., Ghannadi, A., \& Sharif, B. (2003). Anti-inflammatory and analgesic properties of the leaf extracts and essential oil of Lavandula angustifolia Mill. Journal of Ethnopharmacology, 89(1), 67-71.

Hallschmid, M., Benedict, C., Born, J., Fehm, H.-L., \& Kern, W. (2004). Manipulating central nervous mechanisms of food intake and body weight regulation by intranasal administration of neuropeptides in man. Physiology \& Behavior, 83(1), 55-64.

Hanamanthagouda, M. S., Kakkalameli, S. B., Naik, P. M., Nagella, P., Seetharamareddy, H. R., \& Murthy, H. N. (2010). Essential oils of Lavandula bipinnata and their antimicrobial activities. Food Chemistry, 118(3), 836-839.

Herman, A., Bochenek, J., \& Herman, A. P. (n.d.). [Effect of cinnamon and lavender oils on FtsZ gene expression in the Staphylococus aureus ATCC 29213]. Prikladnaia Biokhimiia i Mikrobiologiia, 49(5), 476-480.

Holmes, C., Hopkins, V., Hensford, C., MacLaughlin, V., Wilkinson, D., \& Rosenvinge, H. (2002). Lavender oil as a treatment for agitated behaviour in severe dementia: a placebo controlled study. International Journal of Geriatric Psychiatry, 17(4), 305-308.

Hudson, R. (1996). The value of lavender for rest and activity in the elderly patient. Complementary Therapies in Medicine, $4,52-57$.

Hui, L., He, L., Huan, L., XiaoLan, L., \& AiGuo, Z. (2010). Chemical composition of Lavender essential oil and its antioxidant activity and inhibition against rhinitis-related bacteria. African Journal of Microbiology Research, 4(4), 309-313.

Isman, M. B., Miresmailli, S., \& Machial, C. (2011). Commercial opportunities for pesticides based on plant essential oils in agriculture, industry and consumer products. Phytochemistry Reviews, 10(2), 197-204.

Jenner, P. M., Hagan, E. C., Taylor, J. M., Cook, E. L., \& Fitzhugh, O. G. (1964). Food flavourings and compounds of related structure I. Acute oral toxicity. Food and Cosmetics Toxicology, 2, 327-343.

Joy Bowles, E. (2002). Effects of essential oils and touch on resistance to nursing care procedures and other dementia-related behaviours in a residential care facility. International Journal of Aromatherapy, 12(1), 22-29.

Kasper, S., Gastpar, M., Müller, W. E., Volz, H.-P., Möller, H.-J., Dienel, A., \& Schläfke, S. (2010). Efficacy and safety of silexan, a new, orally administered lavender oil preparation, in subthreshold anxiety disorder - evidence from clinical trials. Wiener Medizinische Wochenschrift, 160(21-22), 547-556. 
Koca Kutlu, A., Çeçen, D., Gürgen, S. G., Sayın, O., \& Çetin, F. (2013). A Comparison Study of Growth Factor Expression following Treatment with Transcutaneous Electrical Nerve Stimulation, Saline Solution, Povidone-Iodine, and Lavender Oil in Wounds Healing. Evidence-Based Complementary and Alternative Medicine, 2013, 1-9.

Kozics, K., Srancikova, A., Sedlackova, E., Horvathova, E., Melusova, M., Melus, V., Krajcovicova, Z., \& Sramkova, M. (2017). Antioxidant potential of essential oil from Lavandula angustifolia in in vitro and ex vivo cultured liver cells. Neoplasma, 64(04), 485-493.

Kritsidima, M., Newton, T., \& Asimakopoulou, K. (2010). The effects of lavender scent on dental patient anxiety levels: a cluster randomised-controlled trial. Community Dentistry and Oral Epidemiology, 38(1), 83-87.

Kumar, V. (2013). Characterization of anxiolytic and neuropharmacological activities of Silexan. Wiener Medizinische Wochenschrift, 163(3-4), 89-94.

Lesage-Meessen, L., Bou, M., Sigoillot, J.-C., Faulds, C. B., \& Lomascolo, A. (2015). Essential oils and distilled straws of lavender and lavandin: a review of current use and potential application in white biotechnology. Applied Microbiology and Biotechnology, 99(8), 3375-3385.

Leung, Y., \& Foster, S. (1996). Encyclopedia of Common Natural Ingredients used in Food, Drugs and Cosmetics.

Li, X.-J., Yang, Y.-J., Li, Y.-S., Zhang, W. K., \& Tang, H.-B. (2016). $\alpha$-Pinene, linalool, and 1-octanol contribute to the topical anti-inflammatory and analgesic activities of frankincense by inhibiting COX-2. Journal of Ethnopharmacology, 179, 22-26.

Lis-Balchin, M., \& Hart, S. (1999). Studies on the mode of action of the essential oil of lavender (Lavandula angustifolia P. Miller). Phytotherapy Research: PTR, 13(6), 540-542.

Lis-Balchin M. (2002). Lavender: The Genus Lavandula. Taylor and Francis.

Mamadalieva, N., Akramov, D., Ovidi, E., Tiezzi, A., Nahar, L., Azimova, S., \& Sarker, S. (2017). Aromatic Medicinal Plants of the Lamiaceae Family from Uzbekistan: Ethnopharmacology, Essential Oils Composition, and Biological Activities. Medicines, 4(1), 8.

Matos, F., Miguel, M. G., Duarte, J., Venâncio, F., Moiteiro, C., Correia, A. I. D., Figueiredo, A. C., Barroso, J. G., \& Pedro, L. G. (2009). Antioxidant Capacity of the Essential Oils From Lavandula luisieri, L. stoechas subsp. lusitanica, L. stoechas subsp. lusitanica x L. luisieri and L. viridis Grown in Algarve (Portugal). Journal of Essential Oil Research, 21(4), 327-336.

Miladinović, D. L., Ilić, B. S., Mihajilov-Krstev, T. M., Nikolić, N. D., Miladinović, L. C., \& Cvetković, O. G. (2012). Investigation of the chemical compositionantibacterial activity relationship of essential oils by chemometric methods. Analytical and Bioanalytical Chemistry, 403(4), $1007-1018$.

Mirzaei F., Keshtgar S., Kaviani M., R. A. (2015). The effect of lavender essence smelling during labor on cortisol and serotonin plasma levels and anxiety reduction in nulliparous women. Journal of Kerman University of Medical Sciences, 16, $245-254$.

Moon, T., Cavanagh, H. M. A., \& Wilkinson, J. M. (2007). Antifungal Activity of Australian Grown Lavandula spp. Essential Oils Against Aspergillus nidulans, Trichophyton mentagrophytes, Leptosphaeria maculans and Sclerotinia sclerotiorum. Journal of Essential Oil Research, 19(2), 171-175.

Mori, H.-M., Kawanami, H., Kawahata, H., \& Aoki, M. (2016). Wound healing potential of lavender oil by acceleration of granulation and wound contraction through induction of TGF- $\beta$ in a rat model. BMC Complementary and Alternative Medicine, 16(1), 144.

Nasiri, A., Mahmodi, M. A., \& Nobakht, Z. (2016). Effect of aromatherapy massage with lavender essential oil on pain in patients with osteoarthritis of the knee: A randomized controlled clinical trial. Complementary Therapies in Clinical Practice, 25, 75-80.

Neves, Â., Rosa, S., Gonçalves, J., Rufino, A., Judas, F., Salgueiro, L., Lopes, M., Cavaleiro, C., \& Mendes, A. (2010). Screening of Five Essential Oils for Identification of Potential Inhibitors of IL-1-induced Nf- $\kappa$ B Activation and NO Production in Human Chondrocytes: Characterization of the Inhibitory Activity of $\alpha$-Pinene. Planta Medica, 76(03), 303-308.

Newman, D. J., \& Cragg, G. M. (2012). Natural Products As Sources of New Drugs over the 30 Years from 1981 to 2010. Journal of Natural Products, 75(3), $311-335$.

Niksic, H., Kovac-Besovic, E., Omeragic, E., Muratovic, S., Kusturica, J., \& Duric, K. (2017). Antiproliferative, antimicrobial, and antioxidant activity of Lavandula angustifolia Mill. essential oil. Journal of Health Sciences, 7(1), 35-43.

Olapour, A., Behaeen, K., Akhondzadeh, R., Soltani, F., al Sadat Razavi, F., \& Bekhradi, R. (2013). The Effect of Inhalation of Aromatherapy Blend containing Lavender Essential Oil on Cesarean Postoperative Pain. Anesthesiology and Pain Medicine, 3(1), $203-207$.

Ou, M.-C., Hsu, T.-F., Lai, A. C., Lin, Y.-T., \& Lin, C.-C. (2012). Pain relief assessment by aromatic essential oil massage on outpatients with primary dysmenorrhea: A randomized, double-blind clinical trial. Journal of Obstetrics and Gynaecology Research, 38(5), 817-822.

Peana, A. T., Marzocco, S., Popolo, A., \& Pinto, A. (2006). (-)-Linalool inhibits in vitro NO formation: Probable involvement in the antinociceptive activity of this monoterpene compound. Life Sciences, 78(7), 719-723.

Prashar, A., Locke, I. C., \& Evans, C. S. (2004). Cytotoxicity of lavender oil and its major components to human skin cells. Cell Proliferation, 37(3), 221-229. Predoi, D., Iconaru, S., Buton, N., Badea, M., \& Marutescu, L. (2018). Antimicrobial Activity of New Materials Based on Lavender and Basil Essential Oils and Hydroxyapatite. Nanomaterials, 8(5), 291.

Rahimzadeh, S., Sohrabi, Y., Heidari, G., Pirzad, A., \& Golezani, K. G. (2016). Effect of Bio-fertilizers on the Essential Oil Yield and Components Isolated from Dracocephalum moldavica L. Using Nanoscale Injection Method. Journal of Essential Oil Bearing Plants, $19(3), 529-541$.

Raja, R. R. (2012). Medicinally Potential Plants of Labiatae (Lamiaceae) Family: An Overview. Research Journal of Medicinal Plant, 6(3), $203-213$.

Salehi, B., Mnayer, D., Özçelik, B., Altin, G., Kasapoğlu, K. N., Daskaya-Dikmen, C., Sharifi-Rad, M., Selamoglu, Z., Acharya, K., Sen, S., Matthews, K. R., 
Fokou, P. V. T., Sharopov, F., Setzer, W. N., Martorell, M., \& Sharifi-Rad, J. (2018). Plants of the Genus Lavandula : From Farm to Pharmacy. Natural Product Communications, 13(10), 1934578X1801301.

Samuelson, R., Lobl, M., Higgins, S., Clarey, D., \& Wysong, A. (2020). The Effects of Lavender Essential Oil on Wound Healing: A Review of the Current Evidence. The Journal of Alternative and Complementary Medicine, 26(8), 680-690.

Sant'Anna Ramos Vosgerau, D., \& Paulin Romanowski, J. (2014). Estudos de revisão: implicações conceituais e metodológicas. Revista Diálogo Educacional, 14(41), 165.

Sarkic, A., \& Stappen, I. (2018). Essential Oils and Their Single Compounds in Cosmetics-A Critical Review. Cosmetics, 5(1), 11.

Schuwald, A. M., Nöldner, M., Wilmes, T., Klugbauer, N., Leuner, K., \& Müller, W. E. (2013). Lavender Oil-Potent Anxiolytic Properties via Modulating Voltage Dependent Calcium Channels. PLoS ONE, 8(4), e59998.

Sharifi-Rad, J., Sureda, A., Tenore, G., Daglia, M., Sharifi-Rad, M., Valussi, M., Tundis, R., Sharifi-Rad, M., Loizzo, M., Ademiluyi, A., Sharifi-Rad, R., Ayatollahi, S., \& Iriti, M. (2017). Biological Activities of Essential Oils: From Plant Chemoecology to Traditional Healing Systems. Molecules, $22(1), 70$.

Shaw, D., Annett, J. M., Doherty, B., \& Leslie, J. C. (2007). Anxiolytic effects of lavender oil inhalation on open-field behaviour in rats. Phytomedicine, 14(9), $613-620$.

Shaw, D., Norwood, K., \& Leslie, J. C. (2011). Chlordiazepoxide and lavender oil alter unconditioned anxiety-induced c-fos expression in the rat brain. Behavioural Brain Research, 224(1), 1-7.

Silva-Filho, S., De Souza Silva-Comar, F., Wiirzler, L., Do Pinho, R., Grespan, R., Bersani-Amado, C., \& Cuman, R. (2015). Effect of Camphor on the Behavior of Leukocytes In vitro and In vivo in Acute Inflammatory Response. Tropical Journal of Pharmaceutical Research, 13(12), 2031.

Silva, G. L. da, Luft, C., Lunardelli, A., Amaral, R. H., Melo, D. A. da S., Donadio, M. V. F., Nunes, F. B., de Azambuja, M. S., Santana, J. C., Moraes, C. M. B., Mello, R. O., Cassel, E., Pereira, M. A. de A., \& de Oliveira, J. R. (2015). Antioxidant, analgesic and anti-inflammatory effects of lavender essential oil. Anais Da Academia Brasileira de Ciências, 87(2 Suppl), 1397-1408.

Smallwood, J., Brown, R., Coulter, F., Irvine, E., \& Copland, C. (2001). Aromatherapy and behaviour disturbances in dementia: a randomized controlled trial. International Journal of Geriatric Psychiatry, 16(10), 1010-1013.

Soltani, R., Soheilipour, S., Hajhashemi, V., Asghari, G., Bagheri, M., \& Molavi, M. (2013). Evaluation of the effect of aromatherapy with lavender essential oil on post-tonsillectomy pain in pediatric patients: A randomized controlled trial. International Journal of Pediatric Otorhinolaryngology, 77(9), 1579-1581.

Spiridon, I., Colceru, S., Anghel, N., Teaca, C. A., Bodirlau, R., \& Armatu, A. (2011). Antioxidant capacity and total phenolic contents of oregano ( Origanum vulgare ), lavender ( Lavandula angustifolia ) and lemon balm ( Melissa officinalis ) from Romania. Natural Product Research, 25(17), 1657-1661.

Sugiura, M., Hayakawa, R., Kato, Y., Sugiura, K., \& Hashimoto, R. (2000). Results of patch testing with lavender oil in Japan. Contact Dermatitis, 43(3), 157160. 2

Takahashi, M., Yoshino, A., Yamanaka, A., Asanuma, C., Satou, T., Hayashi, S., Masuo, Y., Sadamoto, K., \& Koike, K. (2012). Effects of inhaled lavender essential oil on stress-loaded animals: changes in anxiety-related behavior and expression levels of selected mRNAs and proteins. Natural Product Communications, 7(11), 1539-1544.

Tasev, T., Toléva, P., \& Balabanova, V. (1969). Neurophysical effect of Bulgarian essential oils from rose, lavender and geranium. Folia Medica, 11(5), 307317.

Thomford, N. E., Senthebane, D. A., Rowe, A., Munro, D., Seele, P., Maroyi, A., \& Dzobo, K. (2018). Natural Products for Drug Discovery in the 21st Century: Innovations for Novel Drug Discovery. International Journal of Molecular Sciences, 19(6).

Thomson, K. F., \& Wilkinson, S. M. (2000). Allergic contact dermatitis to plant extracts in patients with cosmetic dermatitis. British Journal of Dermatology, $142(1), 84-88$.

Tisserand, R. (1988). The essential oil safety data manual. Tisserand Aromatherapy Institute.

Touati, B., Chograni, H., Hassen, I., Boussaïd, M., Toumi, L., \& Brahim, N. Ben. (2011). Chemical Composition of the Leaf and Flower Essential Oils of Tunisian Lavandula dentata L. (Lamiaceae). Chemistry \& Biodiversity, 8(8), 1560-1569.

Tsai, T.-H., Tsai, T.-H., Chien, Y.-C., Lee, C.-W., \& Tsai, P.-J. (2008). In vitro antimicrobial activities against cariogenic streptococci and their antioxidant capacities: A comparative study of green tea versus different herbs. Food Chemistry, 110(4), 859-864.

Vasireddy, L., Bingle, L. E. H., \& Davies, M. S. (2018). Antimicrobial activity of essential oils against multidrug-resistant clinical isolates of the Burkholderia cepacia complex. PLOS ONE, 13(8), e0201835.

Wells, R., Truong, F., Adal, A. M., Sarker, L. S., \& Mahmoud, S. S. (2018). Lavandula Essential Oils: A Current Review of Applications in Medicinal, Food, and Cosmetic Industries of Lavender. Natural Product Communications, 13(10), $1934578 X 1801301$.

Wittchen, H. U., Jacobi, F., Rehm, J., Gustavsson, A., Svensson, M., Jönsson, B., Olesen, J., Allgulander, C., Alonso, J., Faravelli, C., Fratiglioni, L., Jennum, P., Lieb, R., Maercker, A., van Os, J., Preisig, M., Salvador-Carulla, L., Simon, R., \& Steinhausen, H.-C. (2011). The size and burden of mental disorders and other disorders of the brain in Europe 2010. European Neuropsychopharmacology, 21(9), 655-679.

Woelk, H., \& Schläfke, S. (2010). A multi-center, double-blind, randomised study of the Lavender oil preparation Silexan in comparison to Lorazepam for generalized anxiety disorder. Phytomedicine : International Journal of Phytotherapy and Phytopharmacology, 17(2), 94-99. 
Research, Society and Development, v. 10, n. 5, e23310514933, 2021

(CC BY 4.0) | ISSN 2525-3409 | DOI: http://dx.doi.org/10.33448/rsd-v10i5.14933

Woronuk, G., Demissie, Z., Rheault, M., \& Mahmoud, S. (2011). Biosynthesis and Therapeutic Properties of Lavandula Essential Oil Constituents. Planta Medica, 77(01), 7-15.=

Yazdkhasti, M., \& Pirak, A. (2016). The effect of aromatherapy with lavender essence on severity of labor pain and duration of labor in primiparous women. Complementary Therapies in Clinical Practice, 25, 81-86.

Ziaee, M., Khorrami, A., Ebrahimi, M., Nourafcan, H., Amiraslanzadeh, M., Rameshrad, M., Garjani, M., \& Garjani, A. (2015). Cardioprotective Effects of Essential Oil of Lavandula angustifolia on Isoproterenol-induced Acute Myocardial Infarction in Rat. Iranian Journal of Pharmaceutical Research : IJPR, 14(1), $279-289$.

Zuzarte, M., Gonçalves, M. J., Cavaleiro, C., Cruz, M. T., Benzarti, A., Marongiu, B., Maxia, A., Piras, A., \& Salgueiro, L. (2013). Antifungal and antiinflammatory potential of Lavandula stoechas and Thymus herba-barona essential oils. Industrial Crops and Products, 44, 97-103. 